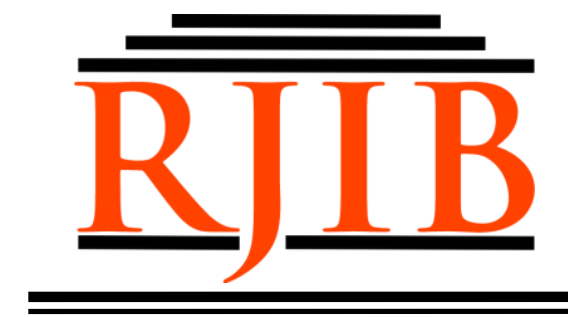

RETORIKA: Jurnal Ilmu Bahasa

Vol. 6, No. 2 October 2020, Page 156-164

P-ISSN: 2406-9019

E-ISSN: 2443-0668

Available Online at https://ejournal.warmadewa.ac.id/index.php/jret

\title{
Semantic Broadening of the Word Sudah in the Spoken Use of Bahasa Indonesia in Sumba
}

\author{
Raynesta Mikaela Indri Malo \\ Universitas Kristen Wira Wacana Sumba \\ raynesta@unkriswina.ac.id
}

\begin{tabular}{|l|}
\hline Received: 03/09/2020 Revised: $12 / 10 / 2020 \quad$ Published: 29/10/2020 \\
\hline How to cite (in APA style): \\
Malo, R. M. I. (2020). Semantic Broadening of the Word Sudah in the Spoken Use of Bahasa Indonesia in Sumba. \\
RETORIKA: Jurnal Ilmu Bahasa, 6(2), 156-164. doi: https://doi.org/10.22225/jr.6.2.2331.156-164
\end{tabular}

\begin{abstract}
This is a descriptive qualitative study which aims at studying the use of the word sudah in the spoken use of Bahasa Indonesia in Sumba. According to Kamus Besar Bahasa Indonesia, sudah is an adverb used mostly to inform that something has already happened or that something has already been done. The position of sudah in phrases or sentences precedes the verb or adjective that it modifies. However, there is a different use of sudah in Sumba, and probably in mostly eastern islands in Indonesia, where this adverb is placed after the verb. The purpose of this research is to study the meaning brought by this new arrangement of sudah. The data was spoken use of Bahasa Indonesia collected through note-taking at campus, houses, and public places (market and stores). The data collected was then analyzed using agih method or meaning-analysis method. There were also 2 informants asked to get information on the function of the new arrangement. The analysis showed that the adverb sudah underwent the semantic or meaning broadening in its use. This study revealed there were 3 new meanings as the result of broadening process, (1) to give order or to ask other people to do something, (2) to invite other people to do something, and (3) to inform that something is about to happen or to be done soon. With these new meanings, the adverb sudah can also function as an adverb to show that something has not happened yet or something has not been done yet, the contrast of what is suggested in the dictionary.
\end{abstract}

Keywords: Meaning broadening; Semantic broadening; Semantic change; Sudah; Widening

\section{INTRODUCTION}

Language is always changing. Since the ancient time up to the present day, every language in the world has been evolved and developed into different form that we are using today (Al-Kadi \& Ahmed, 2018; Baugh \& Cable, 2005). This change can happen across time and space, across continent and social groups. The change also varies. It can be faster or slower, it can be in a great amount or it can be just a small part. Studies on language have shown that language change covers all aspects of language such as pronunciation change, morphology change, semantic/meaning change, and the invention of new words.

Young generation in this millennium may find it difficult to understand what was written by their ancestors hundred years ago. The same thing must happen to the older generation that they cannot easily comprehend what the young generation is saying nowadays. For example, with the advance in technology industry, new words and terminologies are found related to computer and internet. For 
young generation, it is easy to grasp the meaning because they follow the trend. However, for older people born in 1900s, it will be very difficult since these new technologies were not the trend during their time in the past. As the technology replaces old things, it also somehow diminishes the use of old terms. "The most noticeable differences between generations are in vocabulary. What one generation called hi-fi, car phone, and studious young man or woman younger generation calls stereo, cell phone or mobile phone, and (in some instances) nerd (Finegan, 2004).

Changes in language are not only about the coining of new words and disappearing of old words, but also about any other aspects of language. According to Hock and Joseph (2009), there are 5 types of language change: sound change, analogy, semantic change, syntactic change, and change resulting from language contact. Further, Hock and Joseph (2009) explained that sound change refers to the changes in pronunciation, analogy refers to the change in pronunciation of a word affected by other words, semantic change is related to the change of the word meaning, syntactic change is the change in the way words are arranged in a sentence, and the last type refers to the changes that occur when languages are in contact with each other resulting phenomenon such as borrowing, adoption, or adaptation.

In terms of number of words owned by a language, English language now has around 470,000 words (Merriam-Webster Dictionary, 2016). This number is increasing compared to the number of words the language had in the 90s. The same fact also happens to Bahasa Indonesia which had 20,000 entry on its first dictionary. The language now has 127,036 words based on Kamus Besar Bahasa Indonesia (Kamus Besar Bahasa Indonesia, 2016).

There are also changes in pronunciation both in English and Bahasa Indonesia. For the English language, there are Old English (OE) which was used from the year 449 to 1066 AD, Middle English used between 1100-1500, and Modern English pronunciation which has been used since 1500 up to present day (Fromkin et al., 2000). For Bahasa Indonesia, there are at least 4 official stages, (i) Ejaan Van Ophuijsen used in 1901-1947, (ii) Ejaan Republik used in 1947-1972, (iii) Ejaan yang Disempurnakan used in 1972-2015, and (iv) Ejaan Bahasa
Indonesia used since 2015 until now (Pedoman Umum Ejaan Bahasa Indonesia, 2016).

Semantic change also plays an important part in the development of every language. Semantic change or semantic shift refers to the change of the meaning of words from time to time. "There is a general tendency for words to develop new meanings and to relinquish other meanings over time" (Aarts et al., 1993). Bloomfield (1933) and Campbell (1998) defined semantic change as a change in the concepts that were associated with a term and the innovations that change the meaning of words (in Maxilom, 2008).

Murphy \& Koskela (2010) stated a lexical item may develop additional or different senses from the existing ones it has before. In other words, meaning of existing senses of a lexical item may shift and give way for new senses as the old senses become superseded. In other case, the new meaning may develop along with and coexist with the new meaning (in Danzaki, 2015).

Finegan (2004) stated that beside changes in sounds of words, the meaning of terms can also change. About 1000 years ago, the English word starve (Old English steorfan) meant simply 'die' (by any cause). However, the meaning has changed and in today's English. We use the term to refer to the deprivation and death caused by hunger. Another example is the noun meat which once referred to all kind of food, and the word flesh which had a wider meaning than at present, referred to both living flesh and dead flesh as food. Both words have underwent semantic change now. The word gay referred to 'lighthearted' or 'happy' in the past and in modern days, the word is used the most to refer to homosexuals or lesbians.

There are basically several types of semantic changes which can be studied from 2 perspectives (Grondelaers et al., 2012). First is the onomasiological which focuses on a referent, an object or an idea, and analyzes the synchronically and diachronically varying ways of designating that referent. The emphasis is from the function to form. The second is semasiological, which focuses on a linguistic expression and investigates the synchronic and diachronic variation of the objects and ideas that are designated by that expression. In this case the emphasis is from form to function. In the latter perspective, which is the focus in this 
study, semantic change occurs when a particular form gains or loses a meaning. In this sense, "meaning changes, while form remains relatively constant" (Traugott, 2017).

Traugott (2017) classified the language change into several types, (i) metaphorization, the conceptualization of a thing in terms of another, (ii) metonymization, the association of a thing usually in terms of contiguity, (iii) pejoration or the association of a term with negative meaning, (iv) amelioration or the association of a term with positive meaning, (v) narrowing: restriction of meaning, and (vi) generalization: extension of meaning or broadening/widening.

Banks (2004) stated that the meanings of words have been in a constant flux. Words such as lady, which was once a title given in an aristocratic society in $\mathrm{OE}$ and $\mathrm{ME}$ which now has a somewhat pejorative connotation in PDE. Over the centuries, there have been few word meanings that have stayed the same. Some changes have occurred regionally and in different dialects; others have occurred because the next generation has placed a different connotative or, in some cases, denotative meanings on words. Changes occur for any number of reasons; they always have and presumably, they always will. Language is not a fixable entity, and this fact has been proven since OE.

Generalization or the broadening / widening of the meaning of words refers to the phenomenon where the meaning of a word is increasing and becoming broader compared to what it meant originally. Hollmann used the word dog to give an example of broadening. In the past, dog used to refer to some specific large and strong breeds and not to any old dog (Hollmann, 2009). However, in modern day, the word dog has undergone what is known as generalization, widening or broadening. The word is now referred to a highly variable domestic mammal (Canis familiaris) (MerriamWebster Dictionary, 2016), all kind of dog.

In other language beside English, semantic changes also happen. A study on semantic change of the selected Cebuano words from the written texts and spoken language of Cebuano speakers living in Cebu province in the Philippines, revealed that metaphor was the dominant type of semantic change in the written text and broadening was frequentlyused in the spoken language (Maxilom, 2008).
Danzaki (2015) analyzed three major forms of semantic change; expansion or broadening, narrowing or shrinking (specialization) and shift in Arabic loan words in Hausa language. This study revealed that "semantic changes by expansion and narrowing mostly occur due to generalization of a restricted sense and restriction of a generalized sense respectively".

Lexical semantic changes also happen in Bahasa Indonesia, the official language of Indonesia. It is the standardized language and has been used as a lingua franca between ethnic groups in Indonesia, in formal education, government offices, mass media, and others. With hundreds of local groups, local languages or vernaculars are also used by its people. This use of local varieties of language indeed affects the use of Bahasa Indonesia, especially in terms of language or lexical semantic change.

Semantic changes in Bahasa Indonesia have also been studied in several researches. Darheni (2011) showed that Indonesian vocabulary has undergone dynamic development and language change such as through broadening of the meaning (extension of meaning), a narrowing of meaning, pejoration, amelioration, synesthesia, and associations through the years. An example of the broadening in Bahasa Indonesia is the word karantina ('quarantine' in English), which was always associated with isolation of a person because that person is infected by a virus or similar kind of infectious disease. However, the word karantina in today's use of Bahasa Indonesia has more positive meaning than it used to have. It now refers to a place where people are kept together for training or capacity building activities.

Nugraha (2018) studied the expansion of meaning of the word anak ('child' in English) in Bahasa Indonesia. This research shows the extension meaning of the word anak can be described by (a) the idiomatic construction which has six types, i.e. [X+N], [X+ Adj.], [X $+\mathrm{V}],[\mathrm{X}+\mathrm{N}+\mathrm{N}],[\mathrm{X}+\mathrm{N}+\mathrm{V}]$, and $[\mathrm{X}+$ Num. $+\mathrm{N}$ ]. (b) The literal and extension meaning. The literal meaning of the lexeme of child is "second offspring" while the extension meaning approximately has seven meaning, i.e. 'urutan kelahiran', 'manusia yang masih kecil', 'binatang yang masih kecil', 'pohon kecil atau tanaman yang tumbuh pada tumbuh-tumbuhan yang lebih besar', 'orang yang berasal dari 
atau dilahirkan di suatu daerah', 'orang yang termasuk dalam suatu golongan', and 'yang lebih kecil daripada yang lain' ('order of birth', 'a little human', 'a little animal', 'a small tree or plant growing on a larger plant,' one who comes from or is born in an area ',' a person belonging to a class', and 'which is smaller than the others'). (c) Semantic scheme which shows the extension meaning from literal to the domain of extension.

Sembiring (2013) analyzed the semantic/meaning extension of words in a newspaper Pontianak Post. This study revealed that in the political, social, and economic rubric of the newspaper, there were 153 words underwent meaning change, with 118 words experienced broadening/widening of meaning. For example, the word penyakit (illness) basically refers to 1) something that causes trouble in living things; 2) health problems caused by bacteria, viruses, or abnormalities in the physiological system or tissues in the organs of the body (in living things) (Kamus Besar Bahasa Indonesia, 2016). However, the use of the word penyakit in the newspaper shows that the word has wider meaning, which is the social disease in the society.

Banks (2004) stated that the semantic changes can occur to any lexical categories, not only to noun and verbs, but also to adjectives and adverbs. The word sudah in Bahasa Indonesia is an adverb. Based on Kamus Besar Bahasa Indonesia, there are 8 meanings of the word (Kamus Besar Bahasa Indonesia, 2016). (1) 'telah jadi', 'telah sedia', 'selesai' (has become; is available; done), (2) 'habis', 'berakhir' ('finished', 'ended'), (3) 'telah lalu', 'lampau', 'terdahulu' ('past', 'former'), (4) telah: menyatakan perbuatan yang telah terjadi (has already: stated an act that has happened, (5) cukuplah sekian saja (enough), (6) memang demikian; begitulah (halnya) sejak semula (it is the case, the circumstances, etc; it is so from the beginning, (7) sehabis; setelah (after), and (8) berpihak (take sides), used in informal situation.

According to Payne (2011), "any full lexical word that isn't clearly a noun, a verb, or an adjective is often considered to be an adverb". An adverb basically functions as the head of an adverb phrase which modifies a verb (e.g. spoke quietly), an adjective (e.g. really awful), another adverb (e.g. very quietly), or, more rarely, a noun (e.g. the events recently).
Adverbs traditionally are divided into various meaning-related categories, such as adverb of manner (e.g. hurriedly, sideways, thus), adverb of modality (e.g. perhaps, probably, certainly), adverb of time (e.g. later, never, often), adverb of degree or extent (e.g. exceedingly, very), adverb of frequency (e.g. daily) (Aarts et al., 1993) and also adverb of hedging (e.g. sort of, like) and place/location (e.g. over there, here) (Payne, 2011).

Huddleston and Pullum (2005) mentioned that the term 'adverb' is based on the function of these words as modifiers of verbs. However, adverb is also used as modifiers to adjectives; and a good many modify other adverbs as well. We then can determine that adverb functions to modify all categories other than the noun.

Although it can modify almost all categories, the only places an adverb can naturally be placed in a clause are at the beginning (Surreptitiously the dog watched the fluffy cat.), at the end (The dog watched the fluffy cat surreptitiously.), and at the major constituent boundary between the subject and the predicate (The dog surreptitiously watched the fluffy cat.). It can possibly occur between the verb and its object, but this is highly unnatural (Payne, 2011).

Below are some examples of the use of the adverb sudah in sentences in Bahasa Indonesia based on its use in Kamus Besar Bahasa Indonesia.

(a) Saya sudah belajar tadi malam. I (have already) studied last night.

(b) Ia sudah pandai membaca. He is already good at reading.

(c) Bapak sudah berangkat ke Jakarta. Father has (already) left for Jakarta.

(d) Sudah itu ia dipanggil oleh ayahnya. After that, he is called by his father.

(e) Jangan pikirkan yang sudah terjadi. Don't think about what has happened.

The sentences above show that sudah can be placed in a clause and what categories it modifies. In (a) and (c), sudah is located before the verbs (belajar, berangkat) to modify the verbs. In (b), it is placed in front of an adjective (pandai) to modify it. In (d), sudah functions as adverb of time to show what happen after a particular event / time, while in (e) it modifies the verb terjadi in the relative clause yang sudah terjadi. However, in the spoken use of Bahasa Indonesia in Sumba, the adverb sudah 
is also usually used in different arrangement, in which the adverb sudah is placed after the verb. It means that the word sudah may experience semantic or meaning broadening. This study aims at analyzing the use of adverb sudah, as it is used in the spoken language of Bahasa Indonesia in Sumba, and the meaning and functions that it carries.

\section{METHODS}

This study is a descriptive qualitative study. It descriptively elaborated the new meaning of the word sudah as the result of the broadening in the spoken use of Bahasa Indonesia in Sumba. The data was all oral use of language collected through note-taking for 3 months at several places such as campus, house, and public places such as market and stores. The data collected was then selected using meaning-analysis method. Agih method was applied to analyze parts of speech in the sentences. After that, for comparison, the selected data were rearranged to move the position of the word sudah in order to look at how the position of the word affects the meaning. There were 2 informants asked to explain the meaning of the sentences used as the data in this research in order to gain the meaning and see whether the meaning is different from what in the dictionary is.

\section{RESULT AND DISCUSSION}

This section focuses on the semantic change of the word sudah taken from the spoken/oral use (conversation) of people in Sumba island. Examples of the data would be shown before the presentation of the data. From the data provision, there were 23 sentences selected and analyzed to see the broadening of the meaning of sudah. The data were grouped based on the result of the interview with the informants. On the interview, the informants were asked about the whole meaning of each sentences. The result of the interview showed that the meaning of sudah can be divided into three groups as presented below.

\section{To Give Order/Ask Someone to Do}

\section{Something}

\begin{tabular}{|l|l|}
\hline \multirow{2}{*}{1.} & Mandi cepat sudah. \\
\cline { 2 - 2 } & Ordering someone to take a bath quickly. \\
\hline \multirow{2}{*}{2.} & Ade, makan sudah. \\
\cline { 2 - 2 } & Ordering Ade to eat. \\
\hline 3. & Bangun sudah, nanti lambat. \\
\hline
\end{tabular}

\begin{tabular}{|c|c|}
\hline & Ordering someone to wake up. \\
\hline \multirow{2}{*}{4.} & Kasih mati air sudah, sudah penuh. \\
\hline & Ordering someone to turn off the water. \\
\hline \multirow[b]{2}{*}{5.} & Mama jalan sudah duluan, nanti saya ikut. \\
\hline & $\begin{array}{l}\text { Asking the mother to go first and the speaker } \\
\text { will follow. }\end{array}$ \\
\hline \multirow{2}{*}{6.} & Kasih mati sudah itu komputer. \\
\hline & Asking someone to turn off the computer. \\
\hline \multirow{2}{*}{7.} & Tanda tangan sudah di bawah ini. \\
\hline & Asking someone to sign on the paper. \\
\hline \multirow{2}{*}{8.} & Kerja sudah itu tugas. \\
\hline & Ordering students to do the assignment. \\
\hline \multirow[b]{2}{*}{9.} & Bu, pesan sudah makanan untuk rapat. \\
\hline & $\begin{array}{l}\text { Asking someone to order the food for the } \\
\text { meeting. }\end{array}$ \\
\hline \multirow{2}{*}{10.} & $\begin{array}{l}\text { Teman-teman tim, silakan siap sudah } \\
\text { dokumennya. }\end{array}$ \\
\hline & $\begin{array}{l}\text { Asking the team members to prepare } \\
\text { documents. }\end{array}$ \\
\hline \multirow{2}{*}{11 . } & $\begin{array}{l}\text { Semuanya, kumpul sudah tugasnya } \\
\text { sekarang. }\end{array}$ \\
\hline & $\begin{array}{l}\text { Ordering students in class to submit the } \\
\text { assignment. }\end{array}$ \\
\hline \multirow[b]{2}{*}{12.} & Jalan sudah, lampu sudah hijau. \\
\hline & $\begin{array}{l}\text { Asking someone to go because the green } \\
\text { light is on. }\end{array}$ \\
\hline \multirow{2}{*}{13.} & Bayar sudah cepat itu parkir. \\
\hline & Asking someone to pay for the parking. \\
\hline \multirow{2}{*}{14.} & Nona, tolong angkat sudah itu sayur. \\
\hline & Asking the girl to pick up the vegetables. \\
\hline \multirow{2}{*}{15.} & $\begin{array}{l}\text { Kaти ambil sudah itu biskuit nanti saya } \\
\text { bayar. }\end{array}$ \\
\hline & $\begin{array}{l}\text { Asking other people to take the biscuits and } \\
\text { the speaker will pay. }\end{array}$ \\
\hline \multirow[b]{2}{*}{16.} & $\begin{array}{l}\text { Pilih cepat sudah itu bedak, saya mau } \\
\text { pulang. }\end{array}$ \\
\hline & $\begin{array}{l}\text { Asking someone to quickly choose the } \\
\text { powder because the speaker wants to go } \\
\text { home soon. }\end{array}$ \\
\hline \multirow[b]{2}{*}{17.} & Om. Kasih sudah ini sayur 10 ribu. \\
\hline & $\begin{array}{l}\text { Asking the seller (a man) to lower the price } \\
\text { of vegetables to Rp. } 10.000 \text {. }\end{array}$ \\
\hline
\end{tabular}

\section{To Invite}

\begin{tabular}{|c|l|}
\hline \multirow{2}{*}{1.} & Ayo, pulang sudah. \\
\cline { 2 - 3 } 2. & Inviting someone else to go home. \\
\cline { 2 - 3 } 2 Mari kita jalan sudah sekarang \\
\hline \multirow{2}{*}{3.} & $\begin{array}{l}\text { Inviting someone else to go now. } \\
\text { sana. }\end{array}$ \\
\cline { 2 - 2 } & $\begin{array}{l}\text { Inviting someone else to throw the garbage } \\
\text { somewhere else. }\end{array}$ \\
\hline
\end{tabular}

\section{To Inform that Something is about to Happen/to be Done soon}

1. Ini saya print sudah kita punya laporan.

$1 . \quad$ Informing other people that the speaker is 


\begin{tabular}{|c|l|}
\hline \multirow{2}{*}{2.} & $\begin{array}{l}\text { about to print the report soon. } \\
\text { Tungaya start motor sudah sekarang. }\end{array}$ \\
\cline { 2 - 3 } & $\begin{array}{l}\text { Informing someone else that the speaker is } \\
\text { about to turn on the bike and asking the } \\
\text { person to wait in front (of the house). }\end{array}$ \\
\hline \multirow{2}{*}{3.} & $\begin{array}{l}\text { Karena kamu tidak pakai lagi, saya buang } \\
\text { sudah ini kertas semua. }\end{array}$ \\
\cline { 2 - 2 } & $\begin{array}{l}\text { Informing someone else that the speaker is } \\
\text { about to throw away the papers because } \\
\text { they do not use it anymore. }\end{array}$ \\
\hline
\end{tabular}

In all the sentences presented in the data above, it can be seen that sudah is placed after the verb. Some sentences are full sentences with subject and predicate, some are without subject (which actually implied as the listener).

The analysis took only the verb phrase (verb + adverb) which then was compared to the opposite arrangement of adverb + verb as the dictionary suggests. As it is mentioned previously, sudah can be placed before the verbs to modify the verbs, in front of an adjective to modify it and as adverb of time to show what happen after a particular event/time. In the data above, it is possible also to insert another category between the verb and sudah such as in (a) and (p) with adjective (cepat) and in (d) and (v) with noun (air, motor). However, this insertion does not change the imperative meaning of the arrangement. The phrase jalan sudah, buang sudah, and kasih mati sudah are used only once since they appear more than once in the data.

\section{1a) Mandi sudah.}

1b) Sudah mandi

The phrase in 1a shows that the act of mandi or taking a bath has not happened yet. The speaker asks the listener to take a bath, while $1 \mathrm{~b}$ provides the information of $\mathrm{a}$ condition that someone has taken a bath.

\section{2a) Makan sudah}

\section{2b) Sudah makan}

2a shows that the act of makan or eating has not happened yet. The speaker asks the listener to eat. However, 2b supplies the information of a condition that someone has eaten.

3a) Bangun sudah

3b) Sudah bangun

The act of bangun or waking up in 3a has not happened yet. The speaker asks the listener to wake up. However, $3 \mathrm{~b}$ provides the information of a condition that someone has woken up.

\section{4a) Kasih mati sudah}

4b) Sudah kasih mati

4a explains that the act of kasih mati or turning off (i.e. TV or music) has not happened yet. The speaker asks the listener to turn off, while $4 \mathrm{~b}$ shows the information of a condition that something has been turned off.

\section{5a) Jalan sudah}

5b) Sudah jalan

The phrase in 5a indicates that the act of jalan or going (to a direction) has not happened yet. The speaker asks the listener to go (to certain direction). In contrary, $5 \mathrm{~b}$ shows the condition that someone has gone (going to a direction).

6a) Tanda tangan sudah

6b) Sudah tanda tangan

In 6a, the speaker asks the listener to sign on a paper. The act of tanda tangan or signing has not happened yet. However, in $6 \mathrm{~b}$, the act of signing on the paper has been carried out.

7a) Kerja sudah

7b) Sudah kerja

7a shows that the act of kerja or working has not happened yet. The speaker asks the listener to work. However, $7 \mathrm{~b}$ provides information that someone has worked or has done the work.

\section{8a) Pesan sudah}

8b) Sudah pesan

The phrase in 8a indicates that the act of pesan or ordering (i.e. the food) has not happened yet and the speaker asks the listener to order the food. In contrary, the phrase in $8 b$ indicates that something (i.e. the food) has been ordered.

\section{9a) Siap sudah}

9b) Sudah siap

In 9a, the speaker asks the listener to prepare (i.e. document) and the act of siap or preparing has not happened yet. In contrary, 9b provides the information that something has been prepared.

\section{0a) Kumpul sudah}

10b) Sudah kumpul

The act of kumpul or submitting (something) in 10a has not happened yet and the speaker asks the listener to submit (i.e. the assignment). While in $10 \mathrm{~b}$, the act of submitting has been carried out and that something has been submitted. 


\section{1a) Bayar sudah}

11b) Sudah bayar

The act of bayar or paying (using money to pay) in 11a has not happened yet and the speaker asks the listener to pay. In contrary, the act in 11b has been done (something has been paid).

\section{2a) Angkat sudah}

12b) Sudah angkat

12a shows that the act of angkat or picking up has not happened yet and the speaker asks the listener to pick up (i.e. the vegetables). $12 \mathrm{~b}$ on the contrary provides the information of a condition that something has been picked up.

13a) Ambil sudah

13b) Sudah ambil

In 13a, the act of ambil or taking (something) has not happened yet and the speaker asks the listener to take, while in 13b, the act has already happened or something has been taken.

\section{4a) Pilih sudah \\ 14b) Sudah pilih}

14a shows that the act of pilih or choosing has not happened yet. The speaker asks the listener to choose. However, 14b shows the information that someone has chosen something.

\section{5a) Kasih sudah}

15b) Sudah kasih

The act of kasih or giving (something) in 15a has not happened yet and the speaker asks the listener to give (something to listener or other people). In $15 \mathrm{~b}$, the act has been carried out and something has been given (to somebody).

\section{6a) Pulang sudah}

16b) Sudah pulang

16a shows that the act of pulang or going back home has not happened yet and the speaker asks the listener to go home. While in $16 \mathrm{~b}$, the act of going back home has been taken or that someone has gone back home.

\section{7a) Buang sudah}

17b) Sudah buang

The act of buang or throwing something (as garbage) in 17a has not been carried out, while in $17 \mathrm{~b}$ the act has been done.

\section{8a) Print sudah}

18b) Sudah print

In $18 \mathrm{a}$, the act of print or printing has not happened yet and the speaker asks the listener to print (i.e. document). However, $18 \mathrm{~b}$ shows the act of printing has been done.

\section{9a) Start sudah}

19b) Sudah start

The act of starting (i.e. motorcycle) in 19a has not happened yet and the speaker asks the listener to start. However, 19b shows that the action has not been carried out.

The syntactic arrangement of the phrases in 1a23a where sudah is placed after the verb clearly shows that the action of the verb has not been carried out or it has not happened yet. It is the opposite of the use of sudah as an adverb, based on the dictionary, to show that something has already happened or been done. The use of the former and new functions is shown in these examples below.

\section{4a) Rina sudah makan. \\ 24b) Rina, makan sudah!}

The sentence $24 \mathrm{a}$, where sudah is placed before the verb makan, shows that the subject named Rina has eaten (i.e. the food or lunch), while $24 \mathrm{~b}$ where sudah is placed after the verb makan provides the information that the subject Rina has not eaten (the food) yet and is being asked to eat.

\section{5a) Rina sudah pulang.}

25b) Rina, mari pulang sudah!

In $25 \mathrm{a}$, sudah is located before the verb pulang and indicates that the subject named Rina has already gone back home. However, in $25 \mathrm{~b}$, sudah is placed after the verb pulang and shows that the subject named Rina has not gone back home yet and being invited by the speaker to go home. For this function, sentences as in $25 \mathrm{~b}$ usually make use of the particles such as mari and ayo which is used as interjection to invite people to do something.

\section{6a) Saya sudah print dokumennya.}

26b) Saya print sudah dokumennya.

The sentence 26a, in which sudah is placed before the verb print, shows that the subject 'saya' (or 'I') have printed the document. But, the arrangement in 26b, where the verb print is located in front of the adverb sudah, indicates that the action of printing has not been carried out yet and the subject 'saya' as the speaker is informing the listener that she/he is about to print the document.

It can be inferred that there is a general result of the broadening of meaning that sudah can also be used to refer to something that has not happened yet. This broadening also brings 3 new meanings of the word sudah as mentioned above, to give order/to ask someone to do 
something, to invite other people to do something, and to inform or to tell other people that the speaker is about to do something or that something is about to happen soon. Besides, the use of sudah for these new functions also implies that the speaker wants the listener to do something in the near future or as soon as possible after the time of speaking.

It should be noted that the use of sudah with these new meanings usually found in spoken language of Bahasa Indonesia in Sumba Island and in most eastern Indonesia. It can also be found in written text on media social chats and conversation. However, it is hard to find it in the formal use of Bahasa Indonesia such as in printed textbook or newspaper.

As it is used mostly for imperative function in spoken language, the tone of speaker voice also supports the meaning of sudah as a tool to give order. During the data collection, it is clear that when sudah is used for these new functions, the speaker's tone is higher to show the imperative meaning.

\section{CONCLUSION}

This study analyzes the semantic broadening or the broadening of meaning of the adverb sudah in the spoken use of Bahasa Indonesia in Sumba. From the discussion, it can be inferred that the adverb sudah experiences the semantic broadening in its use. As it is mentioned in the dictionary of Kamus Besar Bahasa Indonesia, the adverb sudah is used to modify verb and adjectives and also to function as adverb of time to inform that an occurrence has already happened or that something has already been carried out. In the arrangement, sudah is placed before the verb or adjective which it modifies.

This study reveals that in the spoken use of Bahasa Indonesia in Sumba, sudah is used for different function and carries different meaning through different arrangement in phrases or sentences. There are 3 new meanings brought by the broadening process (1) to give order or asking other people/listener to do something, (2) to invite other people to do something, and (3) to inform that something is about to happen/to be done soon. With these new meanings, the adverb sudah can also function as adverb to show that something has not happened yet or something has not been done yet, the contrast of what is suggested in the dictionary. This is also supported by the arrangement in phrases and sentences where sudah is placed after the verb.

\section{REFERENCES}

Aarts, B., Chalker, S., \& Weiner, E. (1993). The Oxford Dictionary of English Grammar. Oxford University Press.

Al-Kadi, A. M. T., \& Ahmed, R. A. (2018). Evolution of English in the Internet Age. Indonesian Journal of Applied Linguistics, 7(3), 727-736.

Banks, M. A. (2004). Semantic Changes in PresentDay English ( PDE) Semantic Changes in Present-Day English ( PDE ).

Baugh, A. C., \& Cable, T. (2005). A History of the English Language (5th ed.). Pearson Education.

Danzaki, M. A. (2015). Semantic Change in Arabic Loanwords in Hausa. 2nd International Conference on Arabic Studies and Islamic Civilization, March, 448-458.

Darheni, N. (2011). Dinamika Perkembangan Kosakata Bahasa Indonesia Ditinjau dari Aspek Pemaknaan. Jurnal Sosioteknologi, 10(23), 1117-1128.

Finegan, E. (2004). Language: Its Structure and Use. Thomson Wadsworth.

Fromkin, V., Blair, D., \& Collins, P. (2000). An Introduction to Language. Harcourt Australia.

Grondelaers, S., Speelman, D., \& Geeraerts, D. (2012). Lexical Variation and Change. In The Oxford Handbook of Cognitive Linguistics.

Hock, H. H., \& Joseph, B. D. (2009). Language History, Language Change, and Language Relationship: An Introduction to Historical and Comparative Linguistics. Mouton Grammar Library.

Hollmann, W. B. (2009). Semantic Change. In J. Culpeper, F. Katamba, P. Kerswill, \& T. McEnery (Eds.), English Language: Description, Variation and Context (pp. 301313). Palgrave.

Huddleston, R., \& Pullum, G. K. (2005). A Student's Introduction to English Grammar. Cambridge University Press.

Kamus Besar Bahasa Indonesia. (2016). Badan Pengembangan dan Pembinaan Bahasa, Kementerian Pendidikan dan Kebudayaan Republik Indonesia.

Maxilom, R. M. R. (2008). Semantic Change of the Selected Cebuano Words. Proceedings of the 22nd Pacific Asia Conference on Language, Information and Computation, PACLIC 22, 282-289.

Merriam-Webster Dictionary. (2016).

Nugraha, A. D. S. (2018). PERLUASAN MAKNA LEKSEM ANAK DALAM BAHASA INDONESIA. Sirok Bastra. 
Payne, T. E. (2011). Understanding English Grammar. Cambridge University Press.

Pedoman Umum Ejaan Bahasa Indonesia. (2016). PEDOMAN UMUM EJAAN BAHASA INDONESIA Tim Pengembang Pedoman Bahasa Indonesia Badan Pengembangan dan Pembinaan Bahasa Kementerian Pendidikan dan Kebudayaan.
Sembiring, R. J. (2013). Perubahan Makna dalam Rubrik Politik, Sosial, dan Ekonomi pada Harian Pontianak Post. Universitas Tanjungpura.

Traugott, E. C. (2017). Semantic Change. In Oxford Research Encyclopedia of Linguistics (Issue August, pp. 1-23). Oxford University Press. 